\title{
Product Diversification and Its Effects on Bank Spread:The Case of Commercial Banks in Kenya
}

\author{
Jane Isiaho $^{1}$ Prof. Lucky Yona ${ }^{2}$ \\ 1.PHD student, Swiss School of Management \\ 2.Eastern and Southern African Institute of Management
}

\begin{abstract}
This study aimed at evaluating the effect of product diversification on bank spreads. Applying Valverde and Fernández's (2007) extended model of interest spread determinants, the study uses secondary data from commercial banks in Kenya covering the period 2009 to 2018. The data, organized in panel form was analysed using correlation and regression with the help of the PCSE estimator to ensure robustness of results. On the overall, the study found that income diversification and demand deposits ratio have a positive relationship while loans diversification has a negative impact on banks spreads. The results were significant and in similar directions for both spread indicators. These findings lead us to conclude and recommend that banks draw the benefit of risk mitigation by diversifying into various sectors of the economy and indeed this has the result of reducing bank spread. There is therefore need to encourage banks to diversify more and indeed there is an opportunity to do so as the penetration in a good number of sectors was found to still be quite low. Risk-based lending and up skilling of staff in all sectors will go a long way in helping in this endeavour. Income diversification is not yet achieved and commissions and fees are still heavily tied to the making of loans through charging of negotiation fees. Banks need to be encouraged to venture more into non-funds based income streams like insurance, trade facilitation and investment advisory services. With the help of technology, agency networks and general awareness of the population about formal banking, commercial banks have been able to mobilize a lot of demand deposits. They now need to transfer part of the benefits of this to the customer by way of interest earning deposit products for clients with surplus and reduced lending rates for borrowing customers.
\end{abstract}

Keywords: Product Diversification, Bank spread

DOI: $10.7176 / \mathrm{EJBM} / 13-10-10$

Publication date:May $31^{\text {st }} 2021$

\section{Introduction}

Liberalization in the banking industry that began in the early nineties has seen a rise in competition in Kenya's banking sector. This competition, together with the possibilities created by technological innovation, has forced banks to diversify into non-interest based revenue lines and other traditionally non-bank activities like insurance. Technology- based banking and the agency banking proposition has also seen banks further diversify into previously unbanked market segments. Mobile money services have greatly increased access to financial services that has seen loan accounts increase from one million to 3 million between 2007 and 2013 and deposit accounts up from 2 million to 18 million over the same period (Mwega, 2014). As at 2015, the number of customer accounts had grown to 35.1 million, a growth largely credited to the use of the mobile phone to open and operate bank accounts by 3 major banks (FSDK, 2016). Between 2006 and 2019, people seeking financial services from the formal financial sector increased from $27.4 \%$ to $83 \%$ compared to a reduction of those who are considered financially excluded from $29 \%$ to just $8 \%$ over the same period. The financially excluded are those who have no form of access to financial services whatsoever including mobile phone access (FSDK, 2019). This exponential growth in the number of people accessing formal financial services has greatly aided diversification in the banking sector.

\section{Problem statement}

The Ho and Saunders' (1981) dealership model of interest margins has its foundations on the hedging hypothesis and the theory of the banking firm. The model views the bank as a dealer in the deposits and loans market. The bank, in its dealership is faced with a funding or re-investment risk arising from the non-contemporaneous arrival times of loans and deposits. If a loan demand arrives before there is a deposit supply, the bank will have to borrow from the money market to fund the loan demand thus facing a refinancing risk should the money market rates rise. Similarly, if a deposit supply arrives when there is no loan demand, the bank will need to invest the surplus money in the money markets thus facing a reinvestment risk should money market rates fall. To secure a positive return therefore, the bank needs to make loans at a rate higher than the money market rates to cover for the refinance and credit risks. At the same time it needs to accept deposits at a rate lower than the money market rates to cover for the re-investment risk (Maudos \& Fernández De Guevara, 2004). As such interest rate spread is influenced by average size of transactions realized by the bank, interest rate volatility, the degree of risk aversion by bank managers and the structure of the market (Männasoo, 2012). 
The critics of the Ho and Saunders' (1981) dealership model have cited its omission of the costs incurred by banks in the process of their intermediation activities. Later models have been developed to address this by adding on operating costs (Maudos \& Guevara, 2004). The Ho and Saunders dealership model was designed under the assumption of single product loans and deposits. With most countries of the world embracing financial liberalization, the banking industry has in the most part resorted to addressing the increased challenges of competition by diversifying their activities (Mensi \& Labidi, 2015). According to Valverde and Fernández (2007), the introduction of non-traditional activities to the bank's portfolio has the effect of lowering bank spreads. The presence of multiple products creates cross elasticities of demand across the products which eventually narrow the overall bank spread as customers go for the loans with the lowest lending rates and the deposit products with the highest deposit rates. There have been few studies done directly linking product diversification to bank spreads and our current study seeks to fill this gap by carrying out an analysis of the effects of product diversification on bank spreads in Kenya. This study is particularly important in Kenya where there has been a lingering perception that interest spreads charged by commercial banks are too high and inhibitive of access to finance.

\section{Literature review}

\subsection{Product diversification}

Diversification can be defined from many different stand points on the basis of the activities of an organization. Diversification can be focused on products, services or geographical locations. Diversification may refer to the entry to new markets, technological innovation, invention of new products to meet changing needs or new ways of information flow (Otieno, A.O.; Moronge, 2014). Some researchers have defined diversification with respect to products, services or markets. Others are of the view that diversification is about the means by which an organization is able to gain growth while minimizing risk (Mulwa, 2018). Mulwa et al. (2015) sought to define diversification in the context of the banking sector and said it is the combination of different business activities, income sources, assets and liability types by a bank. Diversification is viewed as a strategy employed by banks in the face of competition to help mitigate risk as well as assure continued profitability. When a bank has a welldiversified portfolio, losses realised in one sector either as a result of competitive forces or otherwise, is compensated for by gains made in another (Chen et al., 2013).

With most countries of the world embracing financial liberalization, the banking industry has in the most part resorted to addressing the increased challenges of competition by diversifying their activities (Mensi \& Labidi, 2015). Financial intermediation was necessitated by information asymmetry and transaction costs that seekers and providers of funding would have to encounter in finding each other (Mulwa, 2018). The landscape as far as these two are concerned is quite different in the world now with the emergence of technological innovation in financial circles, emergence of investment groups where people can save and borrow from each other and the general developments in financial markets. This phenomenon has greatly impacted on banks' incomes forcing them to diversify into other sources. Theory has linked such diversification activities with bank spreads.

\subsubsection{Income based diversification}

Income based diversification refers to the expansion of income sources to activities outside the traditional intermediation services (Mulwa et al., 2015). Alongside the developments above is the liberalization of the banking sector which has brought with it competition by way of more commercial banks and more recently, non-bank institutions entering the transactional and lending space hitherto monopolized by banks. This has put a lot of pressure on banks' traditional income sources forcing them to venture into other areas like insurance, wealth management and other non-traditional services in a bid to generate incomes off the balance sheet. Such incomes are commonly referred to as non-interest or non-funded incomes. Banks seek to reduce their risks and enhance profitability by diversifying their income sources. Diversification of income generating activities to avoid overreliance on interest income reduces risk brought about by increased competition in the loans market and the incidence of default (Ismail et al., n.d.). According to Prasetyo (2017), diversified banks maintain a close to equal proportion of interest income to non-interest income. Both Afzal and Mirza (2012) and Ghasemi and Rostami (2015) measured income diversification as the ratio of non-interest income to total assets. According to theory, non-interest incomes reduce bank reliance on interest income from loans and therefore a negative relationship with interest spread is predicted (Afzal, 2011). In their study of determinants of bank spreads in Iran's banking sector, Ghasemi \& Rostami (2015) found a negative relationship between interest rate spread and non-interest incomes.

The study carried out by Dumicic and Ridzak (2016) found that the ratio of non-interest income to total revenue is significant and negative showing that banks with higher proportions of non-interest income reduce interest rates on loans thus narrowing interest rate spread. Banks are willing to substitute loan interest with non-interest incomes and indeed are known to offer lower interest rates to customers who already have products that attract non-interest charges. It is noted that the share of non-interest income significantly dropped after 2008 with reduced lending following the financial crisis suggesting that a greater proportion of the non-interest incomes were drawn from credit related activities in countries in the Central and Eastern Europe.

Among the internal factors studied by Almarzoqi and Naceur (2015) in their research study, the determinants 
of bank interest margins in the Caucasus and Central Asia based on panel data from 110 banks for the period 1998 - 2013 was diversification measured as the ratio of non-interest income to total assets. A well - diversified bank is expected to narrow spread in order to attract new customers and charge higher fees and commissions to compensate for reduced net interest earnings. The correlation between non-interest income and net interest margins was found to be negative and significant, an indication that banks that depend heavily on interest income incur wider margins. It also confirms that banks consider net interest income and non-interest income to be substitutes.

\subsubsection{Loans based diversification}

Diversification is viewed as a strategy employed by banks in the face of competition to help mitigate risk as well as assure continued profitability. When a bank has a well-diversified portfolio, losses realised in one sector either as a result of competitive forces or otherwise, is compensated for by gains made in another (Chen et al., 2013). Diversification in the loans market refers to lending to multiple sectors of the economy. This is often motivated by the desire to grow market share aggressively or spread risks of default as negative economic performance changes do not often impact different sectors in the same way or at the same time. The effect of loans diversification on bank spread occurs in two ways. First is that a diversified bank can compete effectively in a rival's market by engaging in a price competition. A bank that has multiple products may choose one product as a loss leader to edge out a competitor or increase market share. To compensate for the lost profits, the bank will then generate revenues from other products or other markets. Moreover, a diversified portfolio helps a bank mitigate risks of default as adverse effects do not affect all segments and markets at the same time. A properly diversified bank is therefore able to lower its spread by charging lower risk premium (Valverde \& Fernandez, 2007). According to Allen (1988), the presence of multiple products gives customers the choice of the most cost effective financial solution. When the price of one product is raised, it causes a shift of demand to the next product. In the case of banks, this price would be the interest charged on loans and this shifting to products with lower rates eventually brings down the average interest rate spread. According to this view, loan diversification has a negative association with bank spread.

\subsubsection{Demand deposits ratio}

Product features affect prices and in the case of banks, deposit product features are known to influence the interest on deposits. Banks have come up with bundled products that have features like exclusive membership clubs, exclusive service and so on, that are attractive to customers and that are easily traded off for non-interest earning deposit accounts (Gilkeson et al., 1999). This has the ultimate effect of lowering interest paid to depositors thus widening the spread. In the case of Kenya specifically, in the last 10 years following the mobile banking technology revolution, banks have come up with more transaction-based accounts linked to mobile phones which have been a good way of mobilizing cheap and in most cases non-interest earning deposits. This, supported with the onset of agency banking has enabled banks to mobilize more cheap deposits from market segments that could not previously access banking services either due to geographical barriers or costs of maintaining a bank account.

Ghasemi and Rostami (2015) studied the determinants of interest rate spread in Iranian banks using data over 19 months between September 2013 and March 2015. They used descriptive and regression analysis to investigate interest rate spread and the following identified determinants: non-performing loans, ratio of demand deposits to total deposits, non-interest income, interest earnings assets to assets ratio, capital adequacy and return on assets. Of all these the demand deposits to total deposits ratio was found to be most significant with one percentage change resulting to $2.76 \%$ change in interest rate spread. The effect is significant and positive as predicted by theory. Short term time deposits were found to reduce spread due to higher deposit interest rate commitments to maintain the deposits in the study done on Costa Rica (Romero, Jose Pablo Barquero; Rodriguez, 2011).

Afzal and Mirza (2012) based their study of interest rate spread on Pakistan's commercial banking sector in the post financial reform period of 2004-2009. This study introduced the variable public sector share in total deposits to measure the influence of level of interest-insensitive deposits on interest rate spread. The study analysed unbalanced panel data from 25 locally incorporated commercial banks using both descriptive and fixed effects regression analysis. In this study diversification was measured by the proportion of public sector deposits in total deposits and four sectoral diversification variables in the loans market namely: agriculture, textile, energy and consumer. The study found that the proportion of public sector deposits had a statistically significant and positive influence as a higher concentration of these deposits leads to lower interest costs.

\subsection{Bank spread}

Bank interest spread is the dependent variable for this study. Brock and Suarez (2000) define net interest spread as the difference between the cost paid by a borrower to access funds by way of a loan and the return received by a depositor for putting his money in the bank in form of savings (Brock \& Rojas Suarez, 2000). Net interest spread is an indicator of the cost and efficiency of financial intermediation. A high spread tends to stifle economic growth in the sense that low rates on deposits discourages savers hence denying the intermediary the availability of funds to lend out. At the same time, high rates on loans may make the loans unaffordable for borrowers hence limiting investing activities (Ndungu \& Ngugi, 2000). This is especially so in growing economies like Kenya where the 
financial market as an alternative intermediary is under-developed and banks remain the primary source of funds for the rest of the economy.

Whereas the ex-ante spread is the most direct indicator of the actual difference between lending and deposit rates, it is not always easy to get bank level data on the same. Besides, banks charge different lending rates for different product categories and different lending durations. Customers and their businesses also carry different risk profiles and are likely to be charged interest in accordance to their respective risk classes. Deposits also attract different interest rates according to the term and the total relationship value of individual customers. For this reason, it is difficult to find a singular way of measuring the difference between lending and deposit rates (Gounder \& Sharma, 2012). As a result of this, scholars have come up with different ex-post indicators to measure interest rate spread. For this study, we employ two measures used by Valverde and Fernandez (2007) as follows: Interest rate spread to cater for the direct measure of bank spread and gross margin which takes into account incomes from non-traditional activities as well.

\section{Conceptual framework}

As modelled in Valverde and Fernandez' extended model of bank spread determinants, there is a direct relationship between product diversification and bank spreads. Our study will use diversification in incomes, loans and deposits as independent variables and two indicators of bank spread to examine the relationship between product diversification and spread in commercial banks in Kenya. The conceptual framework to guide this examination is shown in the diagram below. This investigation will be carried out with the help of correlation and regression statistical analyses.

Figure 1 Conceptual framework Independent Variables

\section{Dependent Variables}

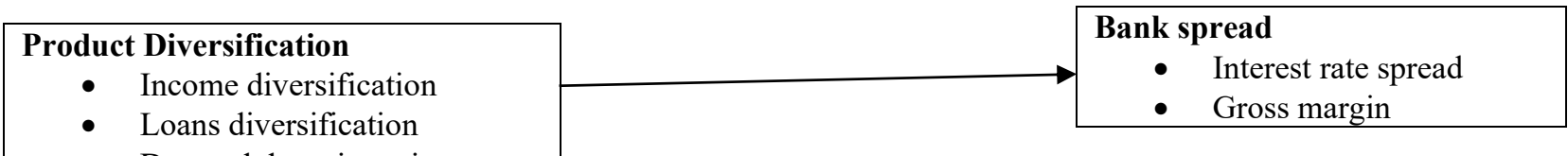

- $\quad$ Demand deposits ratio

Source: Researcher, 2021

\subsection{Independent variables}

\subsubsection{Product Diversification}

Income diversification is proxied by the income diversification index. This index is arrived at as the difference between one and the Herfindahl-Hirschman Index (1-HHI) for the various income streams. Herfindahl- Hirschman Index is defined as the sum of squared shares of the various components of bank operating incomes. Below is the formula that will be used:

\section{$I D I V_{i, t}=1-\mathrm{HHI}=\sum_{i=1}^{n} X_{i t}^{2}$}

Where IDIV is the level of income diversification; HHI the Herfindahl-Hirschman Index is the sum of squared proportions of the various income streams; $X$ is the proportion of income stream $i$ in total income at time $t$ and $n$ is number of income streams the particular bank has (Mensi \& Labidi, 2015; Prasetyo, 2017; Ismail et al., n.d.).

Banks diversify their income sources to avoid over-reliance on interest income in response to competition especially in the loans market. Well diversified banks maintain close to equal proportions of interest income to non-interest incomes. In the Kenyan situation, income streams other than interest income are: commission and fees, foreign exchange or trading income and other operating income. An index of 0.75 therefore indicates full diversification while an index closer to zero would indicate fully specialized income streams (Mensi \& Labidi, 2015). Income diversification improves bank efficiency due to economies of scope (Prasetyo, 2017) which according to the Efficient Markets hypothesis, leads to lower spreads as banks pass the benefit to customers by reducing lending rates or increasing deposit rates. In their study on the determinants of interest rate spread, Ghasemi and Rostami (2015) found a negative relationship between non-interest income and interest rate spread. Afzal (2011) in their study of interest rate spread in an emerging economy based on Pakistan's commercial banks, found no significant relationship with non-interest income. In this study a negative relationship to interest spread is predicted.

Diversification for loans is derived from the measure of concentration of a bank's loans in one sector of the economy. Concentration is often proxied by the Herfindahl-Hirschman Index (HHI). The diversification index is arrived at as one minus the Herfindahl-Hirschman index as shown below. This study identifies 9 different sectors that commercial banks in Kenya lend to namely: Agriculture, Manufacturing, Financial Services, Tourism \& Hospitality, Energy \& Water, Trade wholesale \& retail, Transport \& Communication, Building \& Construction and Personal/Household. The higher the loans diversification index the higher the level of diversification and in this case of 9 sectors, a loans diversification index of 0.89 is indicative of full diversification while an index closer 
to zero indicates specialization. The loans diversification index is arrived at as the difference between one and the Herfindahl-Hirschman Index (1- HHI).

$\mathrm{LDIV}=1-\mathrm{HHI}=\sum_{i=1}^{n} X_{i t}^{2}$

Where,

$L D I V$ is the level of sector diversification; $H H I$ is the Herfindahl-Hirschman Index (HHI), calculated as the sum of squared relative exposures of each loan sector of a bank; $X$ is the proportion of relative exposure of sector $i$ in total portfolio at time $t$ and $n$ is the number of sectors the particular bank is lending to(Mulwa et al., 2015; Turkmen \& Yigit, 2012).

A diversified loan portfolio gives the bank the freedom to compete effectively by lowering prices of some products while compensating for the incomes through other products. At the same time, high concentration of lending to one industry may result in high default rates in the event of adverse economic conditions affecting that sector (Jahn et al., 2013). Turkmen \& Yigit's (2012) study on bank performance in Turkey agrees with the above position. According to them, diversifying loan portfolio means that losses in one sector can be compensated for by gains in another thereby reducing risk and the need for imposing high risk premium of bank spread. A negative relationship with spread is therefore predicted.

The diversification of deposits is often motivated by the desire to reduce the cost of funds by banks. To achieve this they will come up with innovative products, payments solutions and services access that encourage as much of sticky demand deposits as possible. Diversification in the deposits market is measured by the ratio of demand deposits to total deposits in a bank (Afzal \& Mirza, 2012; Ghasemi \& Rostami, 2015). Ghasemi and Rostami (2015) measured this variable as the ratio of low-cost deposits to total deposits and found a significant positive relationship with a numeric value higher than all other variables. His finding is consistent with the theoretical position that a higher proportion of low-cost deposits has the effect of widening spread if loan interest remains notwithstanding the lower cost of deposits. A positive relationship between the demand deposits ratio and bank spread is hypothesized. Based on the discussions above, the following hypotheses are formulated to guide the study.

H1: There is a relationship between product diversification and bank spread of commercial banks in Kenya.

The above hypothesis will be tested together with the following minor hypotheses:

H1a: Income diversification is negatively related with bank spread.

$H 1 b$ : Loans diversification has a negative relationship with bank spread

H1c: There is a positive relationship between demand deposits ratio and bank spread.

\subsection{Dependent variable}

The ex-post calculation of spread takes into account realised interest and therefore controls for the fact that banks with high yields and risky credits are likely to face more defaults. Loans and deposits are not at the same level throughout the year. To achieve a more accurate ratio, this study will be using the ex-post interest spread calculated as the difference between average realised interest income and average realised interest expense. Average realised interest income is derived as the ratio of interest income to average loans and advances whereas the average interest expense is the ratio of interest expense to average deposits (Giordano \& Lopez, 2015). This study also employs a second measure of spread that includes non- interest income to take into account the diversification effect. The calculations for both spread measures are shown below:

(i). IRS $=\frac{\text { Interest earned from loans }}{\text { Average loans }}-\frac{\text { Interest paid on deposits }}{\text { Average deposits }}$

(ii). GRNIM $=\frac{\text { Total } \text { income }_{i, t}}{\text { Total }_{\text {assets }}, t,}$

Where $i$ is the individual bank and $t$ the respective year.

\section{Methodology}

The study was based on commercial banks in Kenya selected through purposive sampling on the basis of available data covering the period under study. The data used was secondary data collected from the selected banks' audited financial statements and analysed in panel data form. Correlation and regression statistics analyses with the aid of SPSS and STATA softwares were used to ascertain the magnitude and direction of influence. In total thirteen banks were selected from the 40 banks in operation as at 2018 . These banks account for $70 \%, 78 \%$ and $72 \%$ of the industry's assets, loans and deposits respectively.

\subsection{Data reliability and validity}

Validity in research refers to the extent to which a concept is accurately measured. It is the degree to which the instrument used measures what it is designed to measure. On the other hand, Reliability is the extent to which results are consistent and replicable (Heale \& Twycross, 2015; Mohajan, 2017). For the multiple regression equation to yield reliable results, the following assumptions must be satisfied: The existence of a normal 
distribution and linear relationship, absence of multicollinearity, auto-correlation and heteroscedasticity. The data was found to be compliant against these tests with the exception of autocorrelation and heteroscedasticity. Table 1 below and appendix figure 1 show the results of the validity tests. To control for the two, the PCSE estimator is used for the regression statistics (Rebei, 2014; Koffie et al., 2014).

Table 1: Validity tests

\begin{tabular}{|c|c|c|c|}
\hline \multicolumn{4}{|c|}{ Multicollinearity tests } \\
\hline & \multirow[t]{2}{*}{ VIF } & \multicolumn{2}{|c|}{ Pearson Correlation coefficients } \\
\hline & & IRS & GRNIM \\
\hline IDIV & 1.353 & $0.405 * *$ & $0.614 * *$ \\
\hline LDIV & 1.398 & $-0.374 * *$ & $-0.364 * *$ \\
\hline DDR & 2.622 & $0.412 * *$ & $0.555^{* *}$ \\
\hline \multicolumn{2}{|c|}{ Autocorrelation tests } & \multicolumn{2}{|c|}{ Normality tests } \\
\hline & Durbin Watson & Kolmogorov-Smirnov & Shapiro Wilk \\
\hline IRS & 0.645 & $0.200 *$ & 0.450 \\
\hline GRNIM & 0.948 & $0.200 *$ & 0.384 \\
\hline
\end{tabular}

Source: Researcher, 2021

\section{Research findings}

\subsection{Descriptive statistics}

Two different measures were used to proxy spread as the dependent variable in this study namely: interest rate spread which captures the spread of traditional intermediation activities and gross margin which captures both traditional and non-traditional banking activities. On the overall the interest rate spread in the banking sector between 2009 and 2018 remained on a downward trend save for 2012 and 2016 (appendix figure 2). Interest rate spread and gross margin overall mean scores are more or less the same (interest rate spread mean of $10.2 \%$ against gross margin of $10.3 \%$ ) suggesting that bank loans form a significant part of banks assets as well as sources of income (Table 2).

Interest Rate Spread is highest among large banks with a mean (SD) of 0.114(.025) closely followed by small banks at a mean (SD) of 0.112(.024) while medium banks posted the lowest mean (SD) of 0.089(.035). Gross margin means follow the same pattern with large banks recording the highest mean (SD) of 0.119(0.018), followed by small and medium banks at $0.107(0.019)$ and $0.090(0.028)$ respectively. There is not much difference in interest rate spread mean (SD) between government and private banks at $0.106(0.018)$ and $0.102(0.034)$ respectively suggesting that interest rate spread in Kenya is driven more by bank size than bank ownership. The scenario is no different for gross margins at mean (SD) of 0.102(0.018) and 0.104(0.028) for government and private banks respectively.

At an income diversification mean (SD) of 0.395(0.095), all commercial banks in Kenya are within the threshold of average to low diversification and their sources of income are more or less the same given that for this study income is considered fully diversified at 0.75 . Indeed, loan interest income made up an average of $75 \%$ of total incomes during the period under review (appendix table A 2). Income diversification index shows a downward trend from a high of 0.4946 in 2010 to a low of 0.3457 in 2016 before rising again to 0.3593 in 2018 . Generally, the changes across the years are smooth, reflective of the nature of bank incomes. Bank products and services tend to be related and change in one is likely to trigger similar change in another. For example, when loans increase, so do the deposit levels as the loans are drawn down, and so do the level of transactions because customers eventually access these funds by way of withdrawal or transfer. Customers use the loaned funds to boost their businesses or whatever other engagement and later bank the proceeds and the cycle continues. The one action of a loan made thereby creates a chain of events that bring in increased revenues touching appraisal fees, interest income and transactional commissions. The converse is true where there is reduced lending and this goes to underscore the reality that incomes in commercial banks are not yet well diversified.

The mean (SD) for loan diversification is more or less equal across large and medium banks at mean (SD) of $0.7634(0.07552)$ and $0.7736(0.09090)$ respectively as shown in the table below. Small banks returned a low mean (SD) for this variable at $0.7283(0.07075)$ suggesting that small banks tend to practise niche lending or are simply limited by their capital base from spreading their activities across a wider clientele. There is a marked variation for government and privately owned banks at mean (SD) of $0.7220(0.05327)$ and $0.7701(0.08566)$ respectively, perhaps an indication that private banks are able to diversify their loan book more either through more deliberate diversification strategies or greater risk appetite. The loans market in Kenya can be said to be fairly well diversified with an overall diversification index mean (SD) of 0.7627(0.08319) against an expected full diversification index of 0.89 as explained earlier. The annual trend for mean (SD) and the maximum diversification index is flat throughout the period under study.

Diversification levels varied across the period with the years 2011 to 2013 recording the highest variations above the overall standard deviation of 0.083 . It would appear that as banks expand their lending activities beyond 
a certain level, the personal/household lending tends to outperform all other segments. In 2017, the personal/household segment made up the highest proportion in total loans at 25\% (CBK, 2017). This might explain why the periods of highest loan growth in 2013 to 2016 saw a reduction in maximum diversification values and an increase in the minimum values thus narrowing the standard deviation from the means

Demand deposit ratio was obtained as the ratio of demand deposits to total deposits. The sector average reveals that $51 \%$ of deposits held by commercial banks are in demand accounts. Here variations by bank size and ownership are evident with large banks holding the largest proportion of $0.6834(0.08229)$ compared to $0.4216(0.13346)$ and $0.3014(0.05960)$ for medium and small banks respectively. As expected, the bank with the highest proportion of demand deposits at $0.7522(0.06745)$ is found among the large banks while the small tier banks posted the least average at 0.3014(0.05960). One large bank stands out with a low proportion of demand deposits at $0.2959(0.03371)$, an indication that this bank plays in a niche market of highly price sensitive clientele. The same bank also posted the lowest income diversification index, a further evidence of the homogeneity of its clients.

Table 2 Descriptive statistics

\begin{tabular}{lccccc}
\hline & IRS & GRNIM & IDIV & LDIV & DDR \\
\hline ALL BANKS & $0.102(0.032)$ & $0.103(0.027)$ & $0.395(0.095)$ & $0.763(0.083)$ & $0.504(0.182)$ \\
LARGE & $0.114(0.025)$ & $0.118(0.018)$ & $0.455(0.059)$ & $0.763(0.075)$ & $0.683(0.082)$ \\
MEDIUM & $0.089(0.035)$ & $0.090(0.028)$ & $0.342(0.080)$ & $0.774(0.091)$ & $0.422(0.133)$ \\
SMALL & $0.111(0.024)$ & $0.107(0.019)$ & $0.404(0.119)$ & $0.728(0.071)$ & $0.301(0.060)$ \\
GOVT & $0.106(0.018)$ & $0.102(0.018)$ & $0.425(0.097)$ & $0.722(0.053)$ & $0.390(0.115)$ \\
PRIVATE & $0.102(0.034)$ & $0.104(0.028)$ & $0.389(0.094)$ & $0.770(0.086)$ & $0.524(0.185)$ \\
\hline
\end{tabular}

\section{Source: Researcher, 2021}

The period under review has had mixed outcomes in terms of economic performance. For the banking industry, it has been a period of significant growth in the midst of steep competition and escalated risks of default in loan servicing. The period between 2009 and 2018 saw the mergers and acquisition of 10 commercial banks(CBK, 2020 ) in a bid to remain in business under this highly competitive environment. The large and medium banks have been the biggest gainers during this period as they have had the financial muscle to be able to take the necessary investments required to reap from the vibrant economy. Their investment in technology, agent outlets and branch presence has enabled them mobilize cheap deposits from segments of the economy that were hitherto unreached thereby posting high demand deposit ratios. Government owned banks, which are in the small size category, with only one in the medium category, were not able to step up to mobilize a lot of the mass market deposits hence the low demand deposit ratios posted throughout the period under this study.

\subsection{Hypothesis testing}

In order to determine the relationship between diversification and bank spread, correlation and regression analyses were done. From the correlations in table 1 above, the relationship between both spread measures, and all the independent variables are significant at the 0.01 level and in the expected direction except for income diversification which returned a positive sign.

The regression coefficients on table 3 show the changes in spread attributable to individual variables as well as the significance of each. The independent variables income diversification, loan diversification and demand deposit ratio account for $31 \%$ of the variance in interest rate spread $\left(r^{2}=0.3053\right)$ and the overall model has predictive power with an overall $p$ value of 0.0000 .. Income diversification effect on interest rate spread is significant and positive $(\mathrm{z}=2.45, p=0.014)$ at $p<0.05$. Every unit change in income diversification results in a 0.08 units' positive change in interest rate spread. This variable was predicted to have a negative sign. The relationship between loans diversification and interest rate spread is negative and significant $(\mathrm{z}=-4.79, p=0.000)$ at $p<0.05$. A unit change in loans diversification results to a 0.11 units' reduction in interest rate spread. The relationship for demand deposits with interest rate spread is also significant and positive as expected $(\mathrm{z}=4.41, p$ $=0.000)$ at $p<0.05$ with a unit change in demand deposits ratio resulting to a 0.042 units' change in interest rate spread. The results for gross margin are all significant with the income diversification and deposits ratios having a positive sign while the loans diversification had a negative sign. Every one unit of income diversification results in a 0.12 units' increase in gross margin, one unit of loan diversification is responsible for a 0.075 units' reduction and one unit of demand deposits ratio leads to a 0.044 units' increase in gross margins. 
Table 3 Linear regression, correlated panels corrected standard errors (PCSEs)

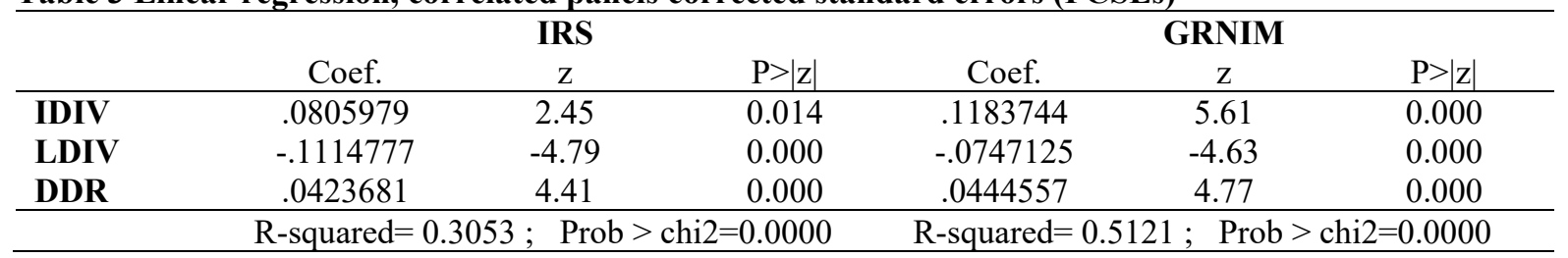

\section{Source: Researcher, 2021}

Contrary to the hypothesized negative relationship between income diversification and interest rate spread, both correlation and regression statistics confirm a positive relationship for this variable. Our hypothesis that there is a negative relationship between income diversification and interest rate spread is therefore not supported. The loans diversification variable is hypothesized to have a negative relationship with bank spread which is supported by the results from both spread measures. The third hypothesis that there is a positive relationship between demand deposit ratio and bank spread is supported by the correlation and regression analyses and the same is significant at the significance levels of 0.01 . The sign for demand deposits ratio is as expected and is evidence that Kenya's banks are reaping the benefits of low cost deposits through wider interest rate spreads.

\subsection{Discussion and conclusion}

On the overall, income sources are not well diversified in Kenya's banking sector with a mean of 0.4043 against a full diversification index of 0.75 . Interest income was found to make up $75 \%$ of total incomes for the 13 banks under this study which is quite significant revealing that Kenya's banking sector is still heavily reliant on interest incomes as the key revenue stream. In his work on income diversification and earnings volatility in Kenya's banking sector,(Kiweu, 2012) found that bigger banks were more diversified than their smaller counterparts. This finding agrees with the conclusion we draw from the current study that large banks are more diversified with a mean (SD) of 0.4552(0.0595) than the smaller ones which posted mean (SD) of $0.3420(0.0797)$ and $0.4036(0.1195)$ for medium and small banks respectively.

The unexpected positive relationship between income diversification and bank spread can be attributed to the interdependence of bank revenue lines for example, loans that earn interest also attract negotiation fees while noninterest bearing deposits which widen spread also increase commissions through transactions. Much as income diversification is a desirable thing in the face of competition in traditional banking services, past studies have cast doubt as to the real benefits of the same. A previous study done by Kiweu (2012) showed that though higher levels of income diversification were often associated with lower lending rates, there was a noted trend of a high positive correlation between non-interest income and interest income leading to the conclusion that there were few benefits if any at all to be expected from income diversification. This is further strengthened by Nisar et al. (2018) surprise findings that fees and commissions had a negative relationship with bank profitability. The explanation for this was said to be the possible correlation between non-interest income and interest income brought about by the cross selling of different products to the same customer. This should be seen in the light of the strategy of most Kenyan banks to increase their wallet share by cross- selling more products to the same customer which is viewed as more profitable. On the overall, Nisar et al. (2018) concluded that income diversification is of benefit to banks if the diversified activities are less risky and of high returns. In a study of the effects of diversification in Korean Banks, Baek and Lee (2015) found that the benefits of the growth of non-interest income were overshadowed by equal growth of non-interest expense thus wiping out the intended gains and shifting the focus for Korean Banks back to interest income.

At an overall loan diversification mean (SD) of $0.7627(0.08320)$, banks in Kenya can be said to be fairly well diversified against a full diversification index of 0.89 . From table 4 below, the bank level findings on loans diversification are confirmed by the industry loans diversification index that remained above 0.80 throughout the period under this study. The most diversified banks were found within the medium and privately owned banks. Loans diversification varies with bank ownership and size. Privately owned banks were found to be more diversified at a mean (SD) of $0.7701(0.08566)$ compared to their government owned counterparts at a mean (SD) of $0.7221(0.05727)$. Medium banks registered the highest diversification index of $0.7737(0.0909)$ closely followed by large banks at $0.7634(0.0755)$ and lastly by small banks at $0.7284(0.0707)$. Though these results still show that bank size does influence diversification, medium banks are slightly more diversified than the large ones probably because they are faced with competition pressures the most and must therefore increase their outreach by increasing their risk appetite more in order to capture market share. This position is supported by their lower interest rate spread of $0.0894(0.0351)$ against that for large banks at $0.1140(0.0250)$ and small banks at 0.1118(0.024). Large banks also have a strong asset capital base and a balance sheet that allows large single borrowings from corporate entities and such values are bound to affect the level of diversification. 
Table 4 Industry sectoral loans diversification index

\begin{tabular}{rrrrrrrrrrr}
\hline$Y E A R$ & 2009 & 2010 & 2011 & 2012 & 2013 & 2014 & 2015 & 2016 & 2017 & 2018 \\
\hline LDIV & 0.837 & 0.837 & 0.843 & 0.850 & 0.844 & 0.842 & 0.848 & 0.845 & 0.845 & 0.841 \\
\hline
\end{tabular}

\section{Source: Researcher, 2021}

In Afzal and Mirza's (2012) study of interest spread determinants in Pakistan, they found that large banks were more diversified than the medium and small ones which were more concentrated on the consumer and textile sector. The situation is slightly different for the Kenyan experience where the medium banks are the most diversified followed closely by large banks. Nevertheless, in both cases small banks were the least diversified. In the Kenyan situation, this could be driven by the small banks' inability to mobilize sufficient mass lending in the level of the medium and large banks. They therefore lend more in niche markets where they also hope the risk is not so high given their small portfolio. In a liberalized banking sector, banks are bound to prefer lending to large corporations and established business enterprises that keep proper financial records as these assist them in making prudent lending decisions. With the development of the consumer lending segment, which by virtue of it being largely unsecured attracts higher risk premiums, banks are shifting more of their lending to this space to reap wider spreads. In Kenya, the risk of non-payment under this segment is extensively mitigated through check-off arrangements with employers. This has ensured high repayment rates and minimized defaults resulting in high interest incomes.

Loans diversification is negative and significant in the correlation analysis for all interest spread indicators. This finding shows that increase in the level of diversification in Kenya's banking sector is strongly associated with reduced interest rate spread. In his study of sectoral credit diversification and bank performance in East Africa's banking industry, Mulwa (2018) observed that there was a significant negative association between diversification and asset quality suggesting that diversification of credit distributes risk hence improving performance. Turkmen and Yigit (2012) made similar conclusions in their study based on Turkish banks where they found a negative association. Atahau, Apriani; Cronje (2017)'s study of how diversification influences portfolio returns based on banks in Indonesia shows that economic sector diversification is associated with greater portfolio returns.

On the demand deposit ratio, large banks have the highest mean (SD) of 0.6835(.0823). Large banks, all of which are notably in the private space, have the capital muscle to deploy technological innovation to their operations and indeed have led the way in the rise of mobile phone based banking technology which has been credited with the growth in deposit accounts from 2 million in 2007 to 35.1 million in 2015 mainly driven by 3 major banks (Mwega, 2014). Indeed, some of the banks have moved from small all the way to large over this period owing to their early adoption of mobile phone based banking technology. This revolution has enabled especially the large banks to mop up cheap deposits from previously unbanked market segments explaining the high demand deposit ratios. With a number of banks recently going under mainly from the small size category, it is understandable that they have the lowest demand deposit ratio mean (SD) of .3015(.0596) and the highest cost to income ratio mean (SD) of $0.9002(0.19213)$ as it must cost them more to mobilize deposits to enable their lending operations.

The relationship with demand deposits is significant and in the expected direction for both the dependent variable indicators. That demand deposits make up over $50 \%$ of the banking sector deposits presents a great opportunity for Kenyan banks to transfer the benefit to its clients by way of a reduced interest rate spread. This however has not happened either due to a lack of sufficient competition in the sector which allows banks to continue lending at high rates or due to the lack of alternative reliable investment vehicles for depositors. In the study done by Afzal \& Mirza (2012) on Pakistan's banking sector, deposits had a negative sign suggesting that Pakistan's deposit market is sensitive to interest rates and banks mobilize deposits by offering higher interest rates. Ghasemi and Rostami (2015) found a significant positive relationship in their study of commercial banks in Iran. This finding is in accordance with theoretical foundations that an increase in demand deposits which are noninterest bearing will result in increased interest rate spread. Kenya's case is a confirmation that banks' strategy to mobilize cheap deposits by use of technology has worked. It could also be a pointer to an under-developed financial sector which does not offer an alternative for investing free cash.

The concentration of demand deposits in the large banks could be an indication that the general population consider other factors more important in deciding to place deposits in the bank than just the interest earning. Some of the factors as already mentioned could be bundled deposit account benefits (Gilkeson et al., 1999), ease of access to transact through technology and bank branch coverage as well as perceived bank stability. If this is the case, then it might be argued that the bulk of bank customers may be indifferent to the deposit interest floor limit under the interest rate cap regime and yet the perceived increased cost led banks to tighten their credit screening resulting in closing out certain sectors from accessing bank credit. An area of further research would be to study customer behaviour in the deposit market in Kenya.

Kenya's banking sector development journey has been punctuated by huge strides in infrastructural changes that have enabled enormous growth of respective bank customer numbers and balance sheets. These developments 
have been made possible through the adoption of agency banking models and technology enabled financial services. These have served to make bank services accessible without the need for physical branch presence. Market power theory posits that diversification enables business growth as it facilitates entry into new markets and exploitation of economies of scale. Such advantage is then used by market players to set competitive prices. In the case of Kenya's banking sector, this appears to be the case for the loans market where this research found to be fairly well diversified with the diversification variable being negatively associated with interest rate spread. Indeed, even before the introduction of interest rate capping in 2016, interest rate spread was on a downward trend for the better part of the study period.

There is need for policies that encourage banks to venture into non-traditional revenue streams like bancassurance and other off balance sheet commissions like guarantees, performance bonds, letters of credit and trade documentary collections to beef up their non-loans related commissions and fees. Given the level of information asymmetry in the financial sector, perhaps it is time banks are encouraged to package financial advice and sell it as a service as well. This will encourage them to cascade information on competitive investment and funding choices to the general public at a fee. It is expected then, that customers will make informed choices that will be cost effective for them whether on where to invest their surplus cash or where to borrow from for their development needs. As banks set themselves to be the customer's choice in either venture, a competition will set in that will naturally bring interest rate spread down.

The rise in demand deposits in commercial banks goes to underscore the fact that the Kenyan population is becoming more receptive to formal financial services. Banks can take advantage of this by ensuring service that delivers value for the customer through provision of timely response to inquiries and requests as well as service availability at all times for the technology supported services. As this delivers value to the customer for their deposits, system stability and quick response to customer issues also saves banks from losses arising due to fraud or litigation which will go a long way in reducing costs and by extension interest rate spread.

The Central Bank has introduced several interventions to address the issue of information asymmetry in the industry. The most current among such measures being credit reference bureaus that should allow banks to access both positive and negative information about the credit standing of customers from a central point. This should enable banks make informed lending decisions thereby reducing risk of default and the resultant costs. Alongside this was the introduction of the requirement for banks to price all their loans using an annual percentage rate and quote the total cost of credit on loan contracts to enable the customer to make informed decisions in terms of cost effectiveness. To support access to this information, Central Bank, in conjunction with the Kenya Bankers' Association came up with a public website called costofcredit where customers can be able to compare the total cost of credit per product for all the banks before making a choice of where to borrow (CBK, 2018). As per CBK's Bank Supervision Report of 2018, the use of this website is still low and there is need to further publicize the same. The gains of this development may also be partly eroded by banks that still require a certain duration of account history with a customer before they can enter into a borrowing contract making it difficult for a customer to make the best choice if that choice is not their current banker especially where their financing need is immediate. There is therefore need to encourage banks to reduce or do away with this requirement by addressing the concerns they might be seeking to mitigate by the account history duration. Strengthening the depth of information available with credit reference bureaus and ensuring the information on the costofcredit website is current and complete will go a long way in addressing information asymmetry in the sector for both the customer and member banks.

The central activity in financial intermediation revolves around maturity transformation. With half of the deposits held in banks being on demand basis, the refinance risk will tend to attract a higher premium that will be covered by lower interest on deposits and higher interest on loans thus widening spread. Banks need to come up with longer term deposit products that help mitigate this risk. This, coupled with an efficient lending process will go a long way to help in closing the gap between interest rate on deposits and loans. The other way to mitigate the refinance risk is for banks to find other more stable sources of funding for their lending activities like long term credit lines from long term investors or development financiers.

\section{Recommendations}

Income diversification in Kenyan banks is low at a mean (SD) of 0.3995(0.09669) signifying overreliance on certain income streams. Though banks have now ventured into non-traditional avenues like insurance, the contribution to total incomes is still quite low and there is need for banks to further increase their efforts to diversify income. Other areas that banks need to consider diversifying into is the area of business advisory services and wealth management which is an area the Kenyan market is ripe for. Income diversification is positively related to interest rate spread, an indication that whereas technology has enabled Kenyan banks to mobilize interest free deposits and widen their base for collection of transactional fees, this benefit has not been passed on to the customer by way of improved deposit rates or cheaper loans.

The loan diversification index is high at an overall mean (SD) of $0.7655(0.08056)$ with private banks recording higher diversification indexes. The private banks are able to achieve this through a combination of more 
aggressive and focussed marketing strategies, wider reach through their branch network and technology and perhaps a higher risk appetite than their government-owned counterparts. The loan diversification variable was found to have a negative relationship with interest rate spread, a pointer to the risk mitigation benefits that diversification has achieved for the sector.This notwithstanding, the loan distribution across sectors is still highly skewed towards only four sectors namely Consumer, Trade, real estate and manufacturing with consumer taking over $25 \%$ of the total lending in the banking industry. All the other sectors of the economy take up less than $10 \%$ of total lending. Government would do well to provide incentives to commercial banks to lend to the sectors with low penetration to stir economic growth in all segments. The regulator and policy makers also need to support and facilitate risk-based lending to further encourage access to loans by all sectors (Dumičić \& Ridzak, 2012).

The relationship between demand deposits ratio and interest rate spread remained positive and significant in both the correlation and regression statistics. The coefficients were also high in all the cases showing that demand deposits have a huge impact on interest rate spread in Kenya's banking sector. At a demand deposit ratio mean (SD) of $0.5078(0.18431)$, over half of deposits held by banks are in non-interest bearing accounts. The trend over the study period is flat indicating that the deposits are sticky. The large banks recorded proportions of demand deposits as high as a mean of $69 \%$ where medium banks had only $42 \%$ and small banks even lower at $30 \%$. This is a reflection of the power of the large banks to mobilize cheap deposits through their large branch presence and ability to deploy technology supported access. Another reality witnessed in the period covered by this research is the flight to safety by depositors to the larger banks considered to be more stable in the wake of bank failures. On the overall, half the deposits held by the banking sector are in transactional accounts that do not earn interest. Banks need to pass on the benefit of cheap deposits to customers by compensating depositors by way of interest or cheaper access to loans.

Given the mass outreach aided by agency banking and mobile phone technology, it would be expected that a lot more deposits are held in transactional accounts. That the other half is held in interest earning accounts goes to demonstrate that the current bank customer is becoming more and more conscious that money in the bank could be put to some gainful use while still at the bank. More Kenyans are beginning to view fixed deposits and other interest earning products offered by banks as a form of liquid investment and therefore seek to maximize on it by negotiating good rates. This further goes to underline the need for banks to come up with investment and wealth management services to take advantage of this awareness in the environment to attract even more deposits. Currently, most bank term deposits do not exceed a tenor of 12 months and this is restrictive of the interest rates paid out. Banks alongside their advisory and wealth management services, need to come up with longer term deposit products with flexible pay-outs that will attract depositors while keeping the banks' costs within reasonable levels as well. This would also eventually help banks match deposits terms to loan terms thereby enabling better management of the interest rate spread.

Further development of the financial market will also serve to introduce a good alternative to banks for provision of finance in addition to being an investment avenue for those with investable funds. Capital markets provide useful financial information on firms thereby enabling the entire financial sector to offer more efficient and cost effective services. Capital markets are a good alternative source of finance with the possibility of even affording more cost effective finance through facilitation of access to foreign financial resources by local investors. Besides, this capital markets also offer savers an alternative assets basket to invest in with the prospect of greater returns than would otherwise be got in keeping the money in a bank savings plan.

This study is significant coming at a time when two major decisions touching on interest spread have been made in quick succession, with one being a decision to reverse the other. Indeed, a number of successive policy interventions have been made since the 1990's to try and address the issue of high interest rate spread without much success, at least judging by the common perception. This study was undertaken to particularly investigate the association between spread and product diversification. Efficiency and product diversification are the two major pre-occupation of banks in Kenya in the wake of technological innovation and it is important to know how these two relate to bank spread in order to make recommendations on where policy makers should focus on as they review regulations in line with the highly automated operating space.

This study was limited to the Kenyan situation and it is recommended that the same is done in other different countries and economic blocks to see if the results are influenced by the different geo-political and economic environments. Another area for further research would be to study customer behaviour in the deposit market in Kenya.

\section{References}

Afzal, A. (2011). Interest Rate Spreads , Loan Diversification and Market Discipline in Pakistan 's Commercial Banking Sector [Lahore School of http://121.52.153.178:8080/xmlui/bitstream/handle/123456789/6535/Dr. Ayesha Thesis.pdf?sequence=3

Afzal, A., \& Mirza, N. (2012). Interest Rate Spreads in an emerging economy: The Case of Pakistan's Commercial Banking Sector. Economic Research, 25(4), 987-1004. https://doi.org/10.1080/1331677X.2012.11517543 
Allen, L. (1988). The Determinants of Bank Interest Margins: A Note. The Journal of Financial and Quantitative Analysis, 23(2), 231. https://doi.org/10.2307/2330883

Almarzoqi, R., \& Naceur, S. Ben. (2015). Determinants of Bank Interest Margins in the Caucasus and Central Asia. In IMF Working Paper (Vol. 87). https://doi.org/10.5042/tldr.2010.0163

Atahau, Apriani; Cronje, T. (2017). Does Diversification Lead to Better Loan Portfolio Returns ? Empirical Evidence from Indonesian Banks. DLSU Business \& Economics Review, 26(2), 25-40.

Baek, S., \& Lee, N. (2015). The Effect of the Diversification in Korean Banks : The impact on Profit and Risk University of North Dakota Seoul National University. Journal of Accounting and Finance, 15(2), 51-69.

Brock, P., \& Rojas Suarez, L. (2000). Understanding the behavior of interest rates and bank spread in Latin America. Working Paper (PUC-NBER) Conference, 63.

CBK. (2017). Central Bank of Kenya.

CBK. (2018). Bank Supervision Annual Report $\quad 2018 . \quad 86$. http://www.centralbank.go.ke/downloads/bsd/annualreports/bsd2010.pdf

CBK. (2020). Mergers \& Acquisitions. https://www.centralbank.go.ke/commercial-banks/mergers-andacquisitions/

Chen, Y., Wei, X., Zhang, L., \& Shi, Y. (2013). Sectoral diversification and the banks' return and risk: Evidence from Chinese listed commercial banks. Procedia Computer Science, 18, 1737-1746. https://doi.org/10.1016/j.procs.2013.05.342

Dumicic, M., \& Ridzak, T. (2016). Determinants of banks' net interest margins in Central and Eastern Europe. ResearchGate, March 2013. https://doi.org/10.3326/fintp.37.1.1

Dumičić, M., \& Ridzak, T. (2012). Determinants of Banks' Net Interest Margins in the CEE.

FSDK. (2013). Supporting the development of inclusive financial markets in Kenya FSD Kenya.

FSDK. (2016). Annual Report 2016. http://www.ifrs.org/-/media/feature/about-us/funding/annual-report-2016.pdf

Ghasemi, A., \& Rostami, M. (2015). Determinants of interest rate spread in banking industry. International Journal of Applied Research, 1(9).

Gilkeson, J. H., List, J. A., \& Ruff, C. K. (1999). Evidence of Early Withdrawal in Time Deposit Portfolios. Journal of Financial Services Research, 15(2), 103-122. https://doi.org/10.1023/A:1008071719082

Giordano, Luca; Lopez. (2015). Competition Versus Efficiency : What Drives Banks ' Spreads in Italian Banking System? Competition versus Efficiency: What Drives B anks '. ResearchGate, June. https://doi.org/10.2139/ssrn.2640899

Gounder, N., \& Sharma, P. (2012). Determinants of bank net interest margins in Fiji, a small island developing state. Applied Financial Economics, 22(19), 1647-1654. https://doi.org/10.1080/09603107.2012.674202

Heale, R., \& Twycross, A. (2015). Validity and reliability in quantitative studies. Evidence-Based Nursing, 18(3), 66-67. https://doi.org/10.1136/eb-2015-102129

Ho, S.Y. Thomas; Saunders, A. (1981). The Determinants of Bank Interest Margins: Theory and Empirical Evidence. Journal of Financial and Quantitative Analysis, XVI(4), 581-601.

Ismail, A., Hanif, R., Choudhary, S., \& Ahmad, N. (n.d.). Income-diversification in banking sector of Pakistan : a 'Blessing' or 'Curse'? Journal of Commerce, 7(1), 11-22.

Jahn, N., Memmel, C., \& Pfingsten, A. (2013). Banks' Concentration Versus Diversification in the Loan Portfolio: New Evidence from Germany. Working Paper, 53.

Kiweu, J. M. (2012). Income Diversification in the Banking Sector and Earnings Volatility: Evidence from Kenyan Commercial Banks. Working Paper Series: Centre for Research on Financial Markets and Policy, WPS/02/12(December), 1-32.

Koffie, A. N., Edder, M., \& Pineda. (2014). Determinants of Banks' Net Interest Margins in Honduras. In IMF Working Paper (Vol. 14, Issue 163). https://doi.org/10.5089/9781498317931.001

Männasoo, K. (2012). Determinants of Bank Interest Spread in Estonia. In Working Paper (1/2012; Working Paper Series, ISSN 1406-7161).

Maudos, J., \& Fernández De Guevara, J. (2004). Factors explaining the interest margin in the banking sector of the European Union. Journal of Banking and Finance, 28, 2259-2281.

Mensi, S., \& Labidi, W. (2015). The Effect of Diversification of Banking Products on the Relationship between Market Power and Financial Stability. American Journal of Economics and Business Administration, 7(4), 185-193. https://doi.org/10.3844/ajebasp.2015.185.193

Mohajan, H. K. (2017). Two Criteria for Good Measurements in Research: Validity and Reliability. Annals of Spiru Haret University. Economic Series, 17(4), 59-82. https://doi.org/10.26458/1746

Mulwa, J. M. (2018). Sectoral credit diversification, bank performance and monitoring effectiveness; a crosscountry analysis of east African banking industries. Journal of Finance and Invesment Analysis, 7(2), 1736.

Mulwa, J. M., Prof, I. I., Tarus, D., \& Kosgei, I. I. I. D. (2015). Commercial Bank Diversification : A Theoretical Survey. International Journal of Research in Management \& Business Studies, 2(1), 45-49. 
Mwega, F. M. (2014). Financial regulation in Kenya: Balancing inclusive growth with financial stability (WP 407; Issue November).

Ndungu, N. S., \& Ngugi, R. W. (2000). Banking Sector Interest Rate Spread in Kenya (DP No 5; Issue 5).

Nisar, S., Peng, K., Wang, S., \& Ashraf, B. (2018). The Impact of Revenue Diversification on Bank Profitability and Stability: Empirical Evidence from South Asian Countries. International Journal of Financial Studies, 6(2), 40. https://doi.org/10.3390/ijfs6020040

Otieno, A.O.; Moronge, M. (2014). Influence of Product Diversification on the Financial Performance of Selected Commercial Banks in Kenya. European Journal of Business Management, 1(11), 1-11.

Prasetyo, M. B. (2017). Diversification and Efficiency in the Indonesian Banking Industry. International Journal of Economics and Management, 11(52), 473-486.

Rebei, N. (2014). Determinants of Interest Rate Spreads in Solomon Islands.

Romero, Jose Pablo Barquero; Rodriguez, C. S. (2011). Determinants of interest rate spread in Costa (No. 032011; Issue 03). Central Bank of Costa Rica, Economic Research Department.

Turkmen, S. Y., \& Yigit, I. (2012). Diversification in Banking and its Effect on Banks' Performance : Evidence from Turkey. American International Journal of Contemporary Research, 2(12), 111-119.

Valverde, C. S; Fernandez, F. R. (2007). The determinants of bank margins in European banking. Journal of Banking and Finance, 31(7), 2043-2063. https://doi.org/10.1016/j.jbankfin.2006.06.017

\section{APPENDIX}

Table A 1 Kenya's percentage annual inflation rate

\begin{tabular}{lrrrrrrrrrr}
\hline & 2009 & 2010 & 2011 & 2012 & 2013 & 2014 & 2015 & 2016 & 2017 & 2018 \\
\hline \%Av. annual inflation & 10.5 & 4.1 & 14 & 9.4 & 5.7 & 6.9 & 6.6 & 6.3 & 8 & 4.7 \\
\% Av. annual T. Bill rate & 7.38 & 3.60 & 8.73 & 12.76 & 8.93 & 8.93 & 10.93 & 8.51 & 8.37 & 7.76 \\
\hline
\end{tabular}

Source: Economic survey (KNBS) and CBK, 2019, 2018, 2017,2016,2014,2012 \& 2011

Table A 2 Proportion of interest income in total income

\begin{tabular}{lr}
\hline ALL BANKS & 0.747 \\
LARGE BANKS & 0.697 \\
MEDIUM BANKS & 0.790 \\
SMALL BANKS & 0.744 \\
GOVERNMENT BANKS & 0.727 \\
PRIVATE BANKS & 0.751 \\
\hline
\end{tabular}

Table A 3 Non -performing loans ratio as at 2018

\begin{tabular}{lccc}
\hline & Loans & Bad debts & NPL ratio \\
\hline GOVT & 56208436 & 34000000 & $60 \%$ \\
PRIVATE & 1674194233 & 196092774 & $11.7 \%$ \\
\hline
\end{tabular}

Table A 4 Income streams proportions

\begin{tabular}{lrrrr}
\hline & Interest Inc & Comm. \& Fees & Forex Inc & Other Ops Inc. \\
\hline Stream & 1258551007 & 242714931 & 106324577 & 54959833 \\
Total & 1662550348 & 1662550348 & 1662550348 & 1662550348 \\
Proportion & $76 \%$ & $15 \%$ & $6 \%$ & $3 \%$ \\
\hline
\end{tabular}

Table A 5 NFI to Total income ratio mean trend

\begin{tabular}{llllllllllll}
\hline & 2009 & 2010 & 2011 & 2012 & 2013 & 2014 & 2015 & 2016 & 2017 & 2018 & Overall \\
\hline Mean & .3031 & .3315 & .2908 & .2254 & .2254 & .2262 & .2231 & .2092 & .2415 & .2176 & .2494 \\
\hline
\end{tabular}




\section{Figure 1 Validity tests}
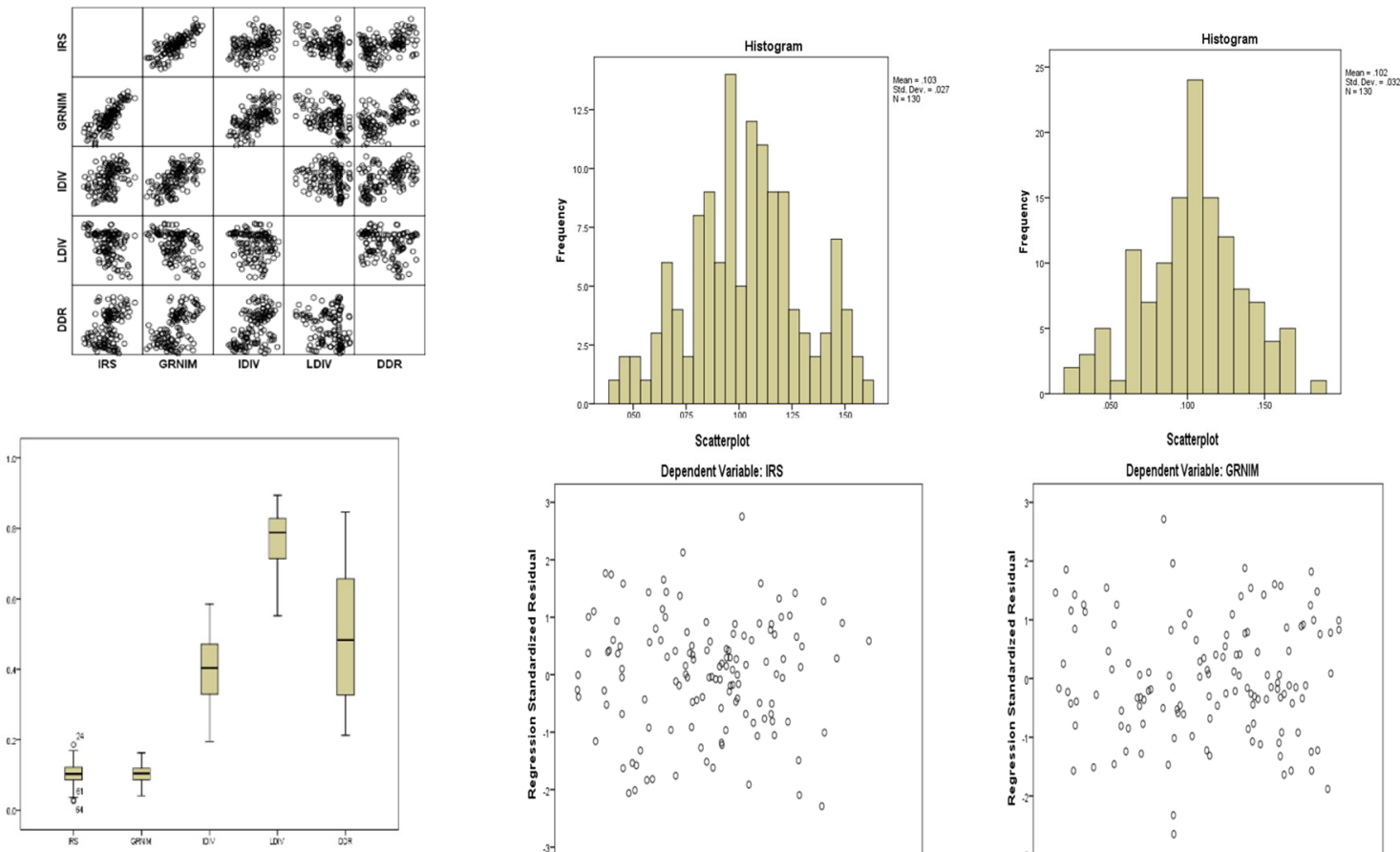

DependentVariable: IRS

Dependent Variable: GRNII
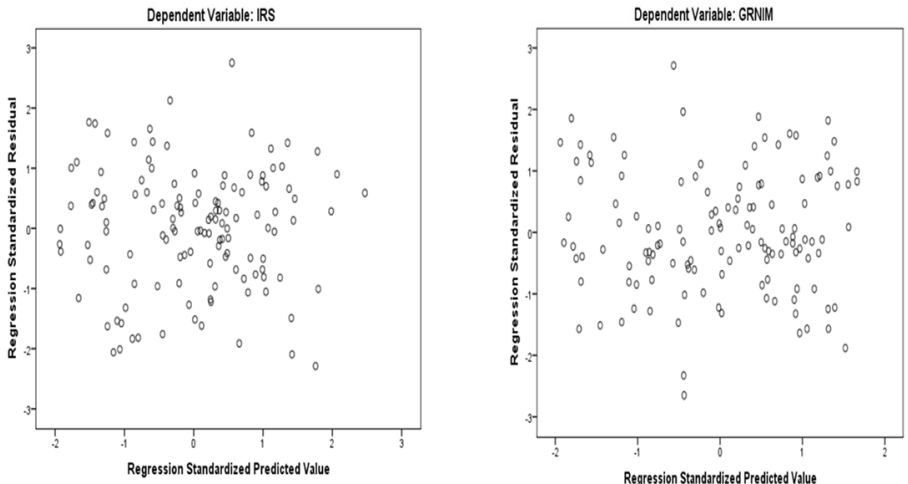

Source: Researcher, 2021

Figure 2 Annual trend analysis for interest rate spread and gross margin

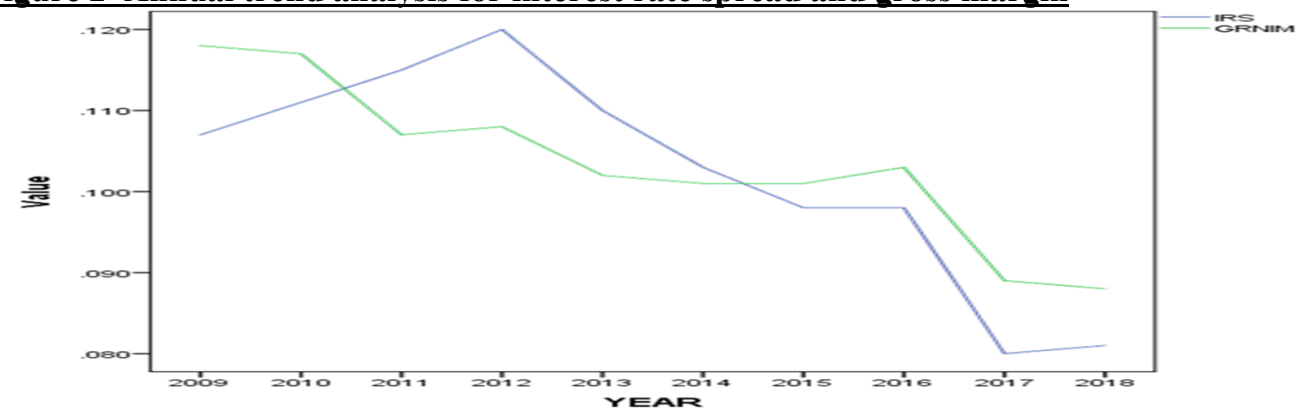

Source: Researcher, 2021 